\title{
The Differences of The Influence of Teaching Method and Self-Reliance on The Students' Learning Outcomes of Long Jump Ortodock Style at SMA Negeri 1 Stabat in the Academic Year2018/2019
}

\author{
AZWAR ANNAS \\ Sports Education \\ State University Of Medan \\ Medan, North Sumatra, Indonesia \\ Azwar.ann20@gmail.com
}

\author{
AMIR SUPRIADI \\ Sports Education \\ State University Of Medan \\ Medan, North Sumatra, Indonesia
}

\author{
IMRAN AHMAD \\ Sports Education \\ State University Of Medan \\ Medan, North Sumatra, Indonesia
}

\begin{abstract}
This Research is conducted by using experimental methods. Experimental research methods are methods used to find the influence of treatment a certain. The research design used was by level $2 \times 2$ with three variable research, one variable and two free variables. As a (the dependent variables) is the result of long jump ortodock style learning and two independent variable is a style of teaching and students' reliance. This research will be held at SMA Negeri 1 Stabat. Phases of this research include the collection of data about the implementation of self-reliance, treat the style of teaching and learning about outcomes data collection the long jump squat style. Implementation of the teaching style of treatment (the reciprocal teaching style and style of teaching practice). As for the timing of the application of the teaching style of treatment (the reciprocal teaching styles and teaching style exercise) done for 4 weeks. By the time the research as much as 4 times.
\end{abstract}

Keywords: Long Jump, Self-reliance, Teaching method .

\section{INTRODUCTION}

Physical education as one of the scope of activities of sports cannot be separated from development and quality improvement efforts in its implementation. Physical education (physical education) is the education business has great potential in an effort to facilitate the development of the learners. Physical education according to Mosston (2008:47) is the only education that stimulate learners to think (cognitive channel) while active physical movement (physical channel) who demanded them to practice fair play (ethical channel) and self-control (social channel).

Implementation of physical education and sport is a long term investment in a quality coaching efforts of West human resources. Therefore, the efforts of the construction for the public and learners through physical education and sport need to continue to do that for the formation of attitudes and motivations and the stirring is performed at every level of formal education.
Physical education is part of education in General. the lesson of physical education is not only focused on learning the physical alone, but also includes three different aspects to be studied. These three aspects are the aspects of psychomotor, cognitive aspects, and affective aspects. Psychomotor aspects with regard to the development of motion as well as motor skills, cognitive aspects to cover the acquisition and application of knowledge in everyday life, while aspects of affective include increasing values social and emotional development.

Regarding to learning that emphasise aspects of motor, then needed a requirement of physical fitness level is good for getting the maximum learning. Physical fitness is the ability of a person to do a long activity without experiencing fatigue. Every effort to increase the physical fitness should develop physical fitness elements.

Athletics is one example of learning materials in physical education which give priority to this aspect of the motor. Athletics has the position as "the mother of sport", that the movement are so complex that almost all kinds of sports adopted the movement from the athletics.

Athletics has several numbers, such as numbers running, throwing, and jump. Number one of the number one in the sport of Athletics was included in the HIGH SCHOOL curriculum is the long jump. The long jump is a sport that requires the precision of a complex body of coordination, strength, and balance. The long jump is a form of movement jumps upward leg lifts to the front in an attempt to bring the point of weight as long as possible in the air (in the air) is done quickly and with the road doing repulsion on one foot to reach distance as far as that. Long jump motion is the movement of a fusion between the velocity (speed), and leap (spring).

The long jump is the result of the beginning speed and repulsion speed away on the board repulsion. In series to reach the long jump was beginning with the sprint dash to 
reach the maximum height of the latter with the perfect landings by trying to avoid the fallen sits in a tub of leap.

There are several styles of long jump that can be taught in school, that is the style of ortodock (tuck), style hang (hang style or sneper), and street style in the air (walking in the air). Tuck style according to Syarifuddin (1992:93) is one of the styles in the long jump while in the air in a State Agency's stance squats, with two bodies gave the knee bent, and his hands forward. The characteristics of the execution style of the squat begins with prefix attitude, attitude, attitude object of repulsion/body in the air (like squats), and the attitude of the landing. The fourth movement is one of unity, one long jump motion sequence that is not disjointed.

The result of observation conducted at SMA Negeri 1 Stabat in academic year of 2019/2020 was found some problems: a lot of students who are not able to control the movement of which should speed up the running time of the beginning and slow running to concentrate on board the focal distance the leap, so many students are still not step on the focal Board/ the focal Board.

Then when the observation was done it turned out that a lot of students complained that they were not to do it, especially female, where they were to do complex movements of the long jump.

The learning motivation of students seemed low during sports learning process, the students were slow when they changed clothes, then when it was told to warm up but they did not do it seriously. And the interview some of the students that they were not interested in learning of physical education, it was boring and exshausting.

The lack of application of physical education with interesting learning, it was impressed that it monotonous and boring.

Student learning outcome was proved that the value of Basic Competencies long jump in the value of mid semester some of them were complete.

The success of the process of teaching and learning activities on learning physical education can be measured from the success of students who followed the event.

The success can be seen from the level of understanding, the mastering of material and learning results students then. The higher understanding, the mastering of material and the results of the study the higher success rate.

To achieve the learning objectives, a teacher must be creative in presenting learning materials in different ways so that the learning materials presented may be well received by the students. Husdarta Yudha M (2000:61). S posited, "skills vary methods in teaching and learning covers three aspects (1) variations in the style of teaching, (2) variation in the use of media and teaching materials, (3) the variation in the interaction between teachers and students.

Teaching style is an important part of the teachers can do to present the subject matter. A teacher should have the ability in presenting learning materials, so the students interested and positive interactions occur between teachers and students. Teaching styles can be done with a variety of variations such as sound, the giving of time, contact point of view, the real teacher position displacement movements etc. From the point of view of students, the teacher performed variations as a dynamic and energetic, so students will be interested in following the given learning task.

Related to teaching the basic techniques of long jump teaching styles are selected the right and easily applied to the students, so the subjects of physical education on the material long jump can be controlled well. The teaching style is the style of the reciprocal teaching, arguing it can menumbuh develop creativity, sense of responsibility and self-reliance of students so as to foster a sense of momentum in the process of learning.

The reciprocal teaching style that has certain characteristics of social interaction, accept, and give immediate feedback. In anatomy, the reciprocal role of teacher's style is to make all of the subject matter, decision criteria, and Logisticals and provide feedback to the observer (Mosston, 2008:116).

The reciprocal method approach gives students the freedom to make decisions with respect to the execution of the assignment, students were given the obligation to assess the results of the study are limited (Rahayu, 2013:151). The assessment is limited to corrective or formatid assessment by a person against a student or group of students.

According to Husdarta (2013:32) this style begins with attention to larger changes, in making the decision of teachers to students. Students are responsible for observing the appearance of a friend or partner and provide immediate feedback on each time doing a movement. In addition to the reciprocal teaching style, also known as some of the styles of teaching. One of the teaching style is a style of teaching practice (practice style). In practice its application teaching style of teachers give students practice and independent, as well as providing time giving feedback (feedback) to students individually and personally this made the student's confidence will be his ability to perform learning activities and materials given by the teacher, and here the teacher explains and demonstrates the tasks of passing control of the foot section in the bottom of the overall to the students.

This style of teaching exercise reduces the dominance of the teacher, assign some responsibility and students are given little freedom to make some decisions with respect to the implementation of activities of the teaching learning process. For instance, decisions on the execution of an order or direction of the teacher. An example in doing the exercises warming, teachers give students freedom.

The purpose of the exercise is a teaching style offers to students the time to do the exercise individually or privately. Also the teacher gives feedback individually and privately. In this style of students also has a role to perform the task, and all the decisions in the implementation of the task was handed over to the students. As for the role of the teacher is to answer questions that students ask and explain the appearance of students and provide feedback at the end of the study (Husdarta, 2013:32).

Not only through teaching style was able to improve the learning results of the long jump but rather the process of 
independence in learning the learners need to know as a contribution in enhancing student learning outcomes. Because the subject the students will always be faced with the situation and dynamics of life is constantly changing and evolving. The trend that emerged at the surface today, supported by the pace of technological development and the current wave of global life difficult and very unlikely to stem.

Independence comes from the word "self" that gets the prefix and suffix to an (Mohammad Asrori, 2009:128). Discussion of self-reliance is a process that concerns the normative elements. This meaning that self-reliance is a process. Because the development of independence in line with the nature of the existential human, then the direction of the development should be in line with and based on the purpose of human life (Mohammad Asrori, 2009:128).

In the context of learning, the negative symptoms that look is less self-sufficient in studying which resulted in a mental disorder at the time of entering the College. The habit of learning outcomes such as teenage problems of HIGH SCHOOL age in this study in which reactive behaviour troubling if associated on the future of the youth. The above symptom is part of the main constraints in preparing individuals capable of wading through the life of the future that is increasingly complex and challenging. According to Mohammad Asrori (2009:128) change values that occur in the generation and between generations will remain positioned self-reliance as the actual issues in human development.

\section{METHOD}

Research was conducted by using experimental methods. Experimental research methods are methods used to find the influence of treatment (treatment) certain (Sugiyono, 2010:12). In this research is to compare two different teaching styles, namely the reciprocal teaching style and style of teaching exercises with variable attribute the independence of students consisting of high independence and self-reliance.

\section{DISCUSSION}

This research aims to obtain the empirical facts about: (1) the difference in the results of the study long jump tuck style among students who were taught with the use of the reciprocal teaching styles and teaching styles of practice, (2) interaction between teaching style with independence against the results of the study long jump tuck-style, (3) the difference in the results of the study long jump tuck style among students with high self-sufficiency is taught using the reciprocal teaching style and style of teaching exercises (4) difference in the results of the study long jump squat style among students with low self-sufficiency is taught using the reciprocal teaching styles and teaching styles of practice.

This research will be held at SMA Negeri 1 Stabat. Phases of this research include the collection of data about the implementation of self-reliance, treat the style of teaching and learning about outcomes data collection the long jump squat style. Implementation of the teaching style of treatment (the reciprocal teaching style and style of teaching practice). As for the timing of the application of the teaching style of treatment (the reciprocal teaching styles and teaching style exercise) done for 4 weeks. By the time the research as much as 4 times.

The research design used was by level $2 \times 2$ with three variable research, IE one variable and two free variables. As a variable (the dependent variable) is the result of long jump squat-style learning and two free variables (the independent variable) is a style of teaching and students 'independence.

Variable treatment learning is differentiated into two, namely the reciprocal teaching styles (A1) and style of teaching practice (A2). Variables that affect, namely independence high (B1) and (B2) low self-sufficiency. the independence of students.

\section{REFERENCES}

[1] Aip, Syarifuddi (1992). Atletik, Departemen Pendidikan dan Kebudayaan

[2] Ega Trisna Rahayu. (2013). Strategi Pembelajaran Pendidikan Jasmani. Implementasi Pada Pembelajaran Pendidikan Jasmani, Olahraga Dan Kesehatan. Bandung: CV Alfabeta.

[3] Husdarta Dan Yudha M. Saputra. (2013). Belajar Dan Pembelajaran Pendidikan Jasmani. Bandung : CV. Alfabeta.

[4] Muska Mosston. (2008). Teaching Physical Education. Finland: University Of Jyvaskyla.

[5] Sugiyono. (2010). Metode Penelitian Pendidikan Pendekatan Kuatitatif, Kualitatif, dan $R \& D$ Bandung: CV. Alfabeta.

[6] Nuril Ahmadi (2007). Panduan Olahraga Bola Voli. Era Pustaka Utama.

[7] Slavin, E. Robert. (2005). Cooperative Learning Teori Riset dan Praktik. Bandung ; Nusa Media. 